\title{
Peranan Manajerial Kepala Sekolah dalam Mengatasi Konflik Guru
}

\author{
Ernaliza ${ }^{凶 1}$, Happy Fitria ${ }^{2}$, Yessi Fitriani ${ }^{3}$ \\ (1) Sekolah Dasar Negeri 12 Sekayu \\ (2) Universitas PGRI Palembang
}

$\triangle$ Corresponding author

[ernalizabarkun@gmail.com]

\begin{abstract}
Abstrak
Tujuan dalam penelitian ini antara lain untuk: 1) mengetahui dan mendeskripsikan bentuk konflik guru; dan 2) mengetahui dan mendeskripsikan peranan manajerial kepala sekolah dalam mengatasi konflik guru. Metode yang digunakan dalam penelitian ini adalah metode kualitatif dengan desain deskriptif. Hasil penelitian: 1) konflik yang terjadi ialah terjadinya kecemburuan sosial akibat kesenjangan antara guru aparatur sipil negara dengan guru honorer, adanya grup antar satu guru dengan guru lainnya, adanya ketidaksukaan dari beberapa guru apabila ada guru yang mendapat penghargaan atas keberhasilan yang dia peroleh dari kepala sekolah maupun dari dinas Dikbud; dan 2) peranan manajerial kepala sekolah dalam mengatasi konflik guru adalah dengan melakukan beberapa tindakan seperti: (a) berusaha netral dan objektif agar tidak terkesan memihak bila terjadi konflik antar guru; (b) selalu memberikan kesempatan berbicara dan berpendapat kepada semua guru; dan (c) selalu memotivasi guru agar fokus pada peningkatan kompetensinya dan pada tugas serta tanggung jawabnya di sekolah.
\end{abstract}

Kata Kunci: Manajerial; Kepala Sekolah; Konflik Guru

\begin{abstract}
The objectives of this study were to: 1) identify and describe the form of teacher conflict; and 2) knowing and describing the managerial role of the principal in resolving teacher conflicts. The method used in this research is a qualitative method with a descriptive design. The results of the study: 1 ) the conflict that occurs is the occurrence of social jealousy due to the gap between state civil servant teachers and honorary teachers, the existence of a group between one teacher and another teacher, the dislike of some teachers if there is a teacher who gets an award for the success he got from the head schools and from the Education and Culture office; and 2) the principal managerial role in resolving teacher conflicts is to take several actions such as: (a) trying to be neutral and objective so as not to appear to be partial in the event of a conflict between teachers; (b) always provide opportunities to speak and argue to all teachers; and (c) always motivating teachers to focus on increasing their competence and on their duties and responsibilities at school.
\end{abstract}

Keyword: Managerial; Principal; Teacher's Conflict

\section{PENDAHULUAN}

Semakin pesatnya perkembangan ilmu pengetahuan, teknologi, informasi, seni, dan budaya yang mendorong adanya perubahan kebutuhan dan kondisi serta menimbulkan tantangan yang semakin kompleks, akan membawa dampak bervariasinya manajemen pendidikan, maka akan banyak tugas bagi para pemimpin pendidikan termasuk kepala sekolah. Dalam menjalankan tugas, seorang kepala sekolah dituntut harus mampu menjadi kepala sekolah yang kompeten terhadap kompleksitas perannya sebagai pemimpin atau manajer.

Sebagai seorang pemimpin, kepala sekolah menjadi promotor bagi masyarakat sekolah terutama para guru, yang arahnya tertuju pada tercapainya visi, misi dan tujuan sekolah (Suratman dkk, 2020; Rulitawati dkk, 2020). Kepemimpinan mencakup tiga arti yakni usaha, kemampuan menjalankan usaha, dan wibawa yang menjadikan seseorang dianggap mampu untuk memimpin. Pemimpin lembaga harus mampu berperan aktif dan mampu menempatkan diri secara strategis dalam mengarahkan lembaganya. Kesuksesan dan keefektifan seorang kepala sekolah dalam memimpin dapat diupayakan dengan saling menghargai, bekerja sama dan memiliki pengetahuan tentang perilaku bawahan (Kristiawan dan Asvio, 2018; Tobari dkk, 2018; Rahmadoni, 2018).

Sebagai manajer, kepala sekolah berperan atau bertugas menyusun program, menyusun organisasi sekolah, menggerakkan staf, mengoptimalkan sumber daya sekolah dan mengendalikan kegiatan. Seorang 
kepala sekolah memiliki peran pokok dalam pengelolaan personalia di sekolah yakni untuk memahami dan menerapkan pengelolaan personalia dengan baik dan benar. Wajib bagi kepala sekolah untuk mendayagunakan personil secara efektif dan efisien agar cita-cita sekolah dapat tercapai secara optimal. Pendidikan merupakan usaha sadar untuk mengembangkan kepribadian dan kemampuan manusia dengan maksud membantu peserta didik mencapai kedewasaan. Pendidikan juga merupakan suatu upaya menuju kearah perbaikan hidup dan kehidupan manusia yang lebih baik.

Untuk menjawab kebutuhan tersebut salah satu permasalahan pendidikan yang dihadapi oleh bangsa Indonesia hingga dewasa ini adalah rendahnya tingkat kinerja guru yang disebabkan oleh permasalahan atau konflik yang terjadi antar guru. Apabila guru mengalami permasalahan atau konflik baik antar guru maupun guru dengan kepala sekolah maka yang terjadi adalah turunnya kinerja guru. Guru adalah pendidik professional dengan tugas utama mendidik, mengajar, membimbing, mengarahkan, melatih, menilai dan mengevaluasi peserta didik pada pendidikan anak usia dini jalur pendidikan formal, pendidikan dasar, dan pendidikan menengah.

Organisasi pendidikan menuntut setiap anggotanya untuk mampu menjalin kerjasama yang baik mengingat bahwa interaksi antara anggota organisasi memiliki kecenderungan timbulnya konflik. Pandangan tradisional menganggap semua konflik buruk. Konflik dipandang secara negatif, dan disinonimkan dengan istilah kekerasan, perusakan dan ketidakrasionalan demi memperkuat konotasi negatifnya. Konflik memiliki sifat dasar yang merugikan dan harus dihindari. Pandangan yang menganggap konflik sebagai hasil disfungsional akibat komunikasi yang buruk, kurangnya keterbukaan dan kepercayaan antara orang-orang, dan ketidak tanggapan manajer (Fathoni dkk, 2013).

Tampubolon (2014) mengemukakan bahwa sebagian besar masyarakat dan manajer memiliki pandangan yang negatif. Konflik dinilai sebagai suatu ancaman, akan tetapi, konflik tidak selalu bermakna negatif tetapi positif (Anwar, 2018). Sebagaimana hasil penelitian yang dilakukan oleh Zulkarnain (2010) menyimpulkan bahwa secara implisit tidak bisa digeneralisasi bahwa konflik sebagai suatu hal yang merugikan ataupun menguntungkan. Dengan demikian, agar konflik dapat meningkatkan kinerja serta produktivitas suatu organisasi, maka pimpinan organisasi tersebut dituntut untuk memiliki kemampuan dalam memanajemen konflik.

Konsekuensi apabila pengelola lembaga pendidikan tidak mampu mengendalikan konflik, maka konflik dapat menjadi masalah yang serius dan akan berpengaruh terhadap efektivitas kerja sekolah. Dalam situasi inilah, dibutuhkan kemampuan mengelola situasi konflik antar personil sekolah, agar tidak berkembang dan dijadikan sebagai modal untuk meningkatkan kinerja. Sebagaimana hasil penelitian yang dilakukan oleh Wartini (2015) bahwa strategi manajemen konflik berpengaruh secara positif dan signifikan terhadap kinerja teamwork tenaga kependidikan. Kemudian hasil penelitian Liu (2010) yang menyatakan bahwa relationship conflict reduces team cohesiveness and both relationship and task conflicts are negatively related to firm performance. With relationship conflict, the results show using compromising approach could help reduce its negative effects on TMT cohesiveness and firm performance; but avoiding either type of conflict will undermine both team and firm outcome.

Konflik hubungan dapat mengurangi kekompakan tim dan kedua konflik hubungan dan tugas yang berhubungan negatif dengan kinerja. Sebagaimana hasil penelitian dari Arisandi dkk (2017) yang menunjukkan bahwa terdapat pengaruh langsung positif dan signifikan kepemimpinan kepala sekolah dalam manajemen konflik berbasis sekolah terhadap kinerja guru. Semakin baik strategi manajemen konflik dilakukan oleh kepala sekolah maka akan semakin dapat meningkatkan kinerja teamwork tenaga kependidikan yang hasilnya dapat diukur melalui terciptanya keharmonisan kerja, terjalinnya komunikasi yang terbuka, adanya pertimbangan akan efektivitas dan efisiensi kerja serta terbuka dalam penggunaan metode-metode untuk membantu dalam penyelesaian pekerjaan. Sebagaimana yang dikemukakan oleh Isrofi (2017) bahwa efektivitas kepemimpinan seseorang dapat dinilai dari bagaimana ia mampu mengendalikan dan mengelola konflik.

Penelitian ini dilaksanakan di Sekolah Dasar Negeri 2 kecamatan Sekayu, Sekolah Dasar Negeri 2 kecamatan Sekayu merupakan salah satu sekolah dasar yang memiliki tenaga pendidik dengan jumlah yang cukup besar dibandingkan dengan sekolah dasar lainnya yaitu 23 guru yang terdiri dari 13 guru berstatus ASN dan 10 guru berstatus tenaga honorer. Jumlah guru yang cukup besar serta perbandingan antara jumlah guru ASN dan honorer yang tidak terlalui jauh sangat berpotensi menimbulkan konflik baik itu yang bersifat horizontal maupun pertikal. Seperti halnya suatu organisasi, dimana lembaga pendidikan tidak akan terlepas dari potensi munculnya konflik baik itu konflik antar kepala sekolah dan guru, konflik antara guru dan guru serta konlik emosional guru saat melaksanakan proses pembelajaran.

Berdasarkan hasil observasi awal yang telah dilakukan oleh peneliti pada bulan Mei hingga Juli 2020, Sekolah Dasar Negeri 2 kecamatan Sekayu termasuk sekolah yang tidak dapat terlepas dari konflik. Adapun jenis konflik guru yang terjadi di Sekolah Dasar Negeri 2 kecamatan Sekayu, antara lain: (1) konflik tugas karena ketidaksesuaian tugas yang dijalankan beberapa guru dengan kemampuan, pengetahuan, pendidikan, keterampilan; (2) konflik antarpersonal, dimana terjadinya konflik seperti kecemburuan sosial akibat 
kesenjangan antara guru yang berstatus Aparatur Sipil Negara dan honorer, konflik hubungan antar individu karena terdapat ketidak sepakatan personal terhadap kebutuhan dan kepentingan individu di sekolah dan (3) konflik prosedural ketika beberapa guru di sekolah tidak sepakat tentang prosedur dalam mengatur bagaimana cara sekolah melakukan manajemen.

Pemicu terjadinya konflik di Sekolah Dasar Negeri 2 kecamatan Sekayu, seperti adanya kecemburuan sosial akibat kesenjangan antara guru yang berstatus Aparatur Sipil Negara dan honorer. Konflik tersebut terlihat dari sikap yang muncul baik itu dari guru yang berstatus ASN maupun dari guru honorer, beberapa guru yang berstatus ASN terlihat kurang menghargai guru yang berstatus honorer seperti membicarakan sertifikasi guru didepan guru honorer yang jelas tidak mendapatkan tunjangan sertifikasi. Guru yang berstatus sebagai ASN juga lebih suka berkomunikasi dengan guru yang berstatus ASN dan kurang terlihat memiliki hubungan yang harmoni dengan guru honorer. Sementara guru honorer juga menganggap hal ini dengan sikap yang sama. Guru honorer menganggap mereka memiliki hak yang sama dengan guru yang berstatus ASN di sekolah tersebut.

Selain itu, adanya group antara satu guru dengan guru yang lain juga menimbulkan konflik perbedaan sudut pandang yang dapat memicu perselisihan diantara guru di Sekolah Dasar Negeri 2 kecamatan Sekayu. Guru yang memiliki gaya hidup yang sama lebih menyukai untuk selalu berinteraksi dengan guru yang memiliki pemikiran yang sama, sementara guru yang lain kemudian memberikan penilaian yang negatif atas gaya hidup yang tidak sejalan dengan sudut pandangnya. Konflik ini juga dinilai oleh peneliti sebagai pemicu perselisihan antara guru satu dengan guru lainnya.

Permasalahan yang sangat menonjol adalah beberapa guru yang dinilai memiliki kompetensi yang lebih tinggi dan selalu mendapatkan apresiasi dari kepala sekolah maupun Dinas Pendidikan memicu ketidak sukaan dari beberapa guru yang menganggap bahwa prestasinya itu biasa-biasa saja dan tidak layak untuk diberikan apresiasi dan penghargaan. Beberapa guru yang dinilai memiliki kompetensi dan selalu diandalkan oleh kepala sekolah dalam setiap kegiatan akademis mendapat respon yang kurang baik dari beberapa guru di Sekolah Dasar Negeri 2 kecamatan Sekayu. Konflik dari permasalahan ini lebih terlihat dari sikap yang muncul yang diakibatkan dari konflik ini.

Hal tersebut yang pada akhirnya dapat menjadi cikal bakal adanya konflik yang terus menerus terjadi di Sekolah Dasar Negeri 2 kecamatan Sekayu, dikarenakan adanya keterbatasan yang tidak menutup kemungkinan akan memunculkan pertanyaan mengenai hak, keadilan dan kebijaksanaan atasan terhadap bawahannya.Pengelolaan konflik di Sekolah Dasar Negeri 2 kecamatan Sekayu sudah dilaksanakan oleh kepala sekolah dengan melakukan beberapa tindakan seperti berusaha netral dan objektif agar tidak terkesan memihak bila terjadi konflik antar guru. selain itu kepala sekolah selalu memberikan support keseluruh guru tidak terkecuali dan memberikan kesempatan berbicara yang sama kepada semua guru di Sekolah Dasar Negeri 2 kecamatan Sekayu.

Kepala sekolah selalu mendorong agar guru dapat bekerja keras untuk meningkatkan kompetensi dan fokus kepada tugas dan tanggungjawabnya disekolah. Tindakan yang dilakukan oleh kepala sekolah dalam mengelola konflik di Sekolah Dasar Negeri 2 kecamatan Sekayu belum dapat memberikan jawaban mendalam "apakah kepala sekolah sebagai manajer telah melaksanakan perannya dengan maksimal dalam mengelola konflik"?

Hasil observasi awal yang dilakukaan oleh peneliti dapat dijadikan acuan bagi peneliti untuk melakukan penelitian lebih dalam lagi tentang bagaimana kepala sekolah sebagai manajerial dapat mengelola dan mengatasi konflik yang terjadi di sekolah dengan cara menyikapi konflik yang bersifat produktif. Konflik yang bersifat fungsional dapat diselesaikan dengan meningkatkan kualitas tanggung jawab personal, kelompok kerja maupun organisasi sehingga melahirkan perubahan pola pikir maupun hasil. Selain itu, penelitian ini juga berusaha untuk mengurai lebih dalam bagaimana kepala sekolah dapat menyelesaikan konflik disfungsional dengan membuat saling pengertian dan pemahaman antar individu dengan mendistribusikan kepentingan yang adil sesuai dengan tanggung jawab melalui prosedur kerja yang bertujuan untuk meningkatkan kinerja sekolah.

Berdasarkan latar belakang yang telah diuraikan diatas, maka peneliti tertarik untuk mengadakan penelitian dengan judul peranan manajerial kepala sekolah dalam mengatasi konflik guru di Sekolah Dasar Negeri 2 kecamatan Sekayu.

\section{METODE PENELITIAN}

Penelitian ini mengunakan metode deskriptif kualitatif. Moleong (2011) menyebutkan penelitian kualitatif sebagai prosedur penelitian yang menghasilkan data deskriptif berupa kata-kata tertulis atau lisan dari orang-orang dan prilaku yang dapat diamati, dimana metode yang digunakan menekankan pada proses penelusuran data/informasi hingga dirasakan telah cukup digunakan untuk membuat suatu interpretasi. Kemudian Iskandar (2012) mengemukakan bahwa penelitian kualitatif adalah penelitian yang berpegang kepada paradigma naturalistik atau fenomenologi tentang apa yang dipahami oleh subjek penelitian misalnya perilaku persepsi, motivasi, tindakan, dan lain-lain, secara holistik, dan dengan cara deskripsi dalam bentuk 
kata-kata dan bahasa, pada suatu konteks khusus yang alamiah dan dengan memanfaatkan berbagai metode ilmiah. Metode yang digunakan dalam penelitian ini adalah metode kualitatif dengan desain deskriptif, peneliti akan menjelaskan dan mendeskripsikan penanganan konflik guru dan jenis jenis konflik guru yang terjadi di Sekolah Dasar Negeri 2 Kecamatan Sekayu.

Adapun populasi dan informan dalam penelitian ini adalah: 1) informan kunci, adalah kepala sekolah, bendahara sekolah, para guru, dan operator sekolah SD negeri 2 kecamatan Sekayu; 2) tempat dan peristiwa, dimana peneliti memperoleh data antara lain meliputi proses belajar mengajar, proses pengambilan keputusan, rapat-rapat dewan guru, sosialisasi dan pengelolaan program, serta proses pengelolaan kelembagaan; 3) dokumen, antara lain meliputi, daftar nama dan jabatan guru, prestasi sekolah, prestasi siswa dan guru, kondisi sarana prasarana, profil sekolah dan lain-lain. Data ini dipergunakan untuk melengkapi hasil wawancara dan pengamatan terhadap tempat dan peristiwa.

Teknik pengumpulan data dalam penelitian ini menggunakan teknik observasi, wawancara, dokumentasi studi kepustakaan. Teknik analisis data yang digunakan dalam penelitian ini meliputi reduksi data, penyajian data dan penarikan kesimpulan. Data yang telah diperoleh melalui alat pengumpul data yaitu hasil wawancara, dokumentasi, observasi dan kajian pustaka yang telah dikumpulkan akan diolah dengan menggunakan penelitian kualitatif, lalu melakukan analisis domain untuk memperoleh gambaran secara umum dan menyentuh pada objek penelitian melalui proses yang terdiri dari proses reduksi data, display dan verification (Miles dan Huberman, 2013).

\section{HASIL DAN PEMBAHASAN}

\section{Tipe Kepemimpinan Kepala SD Negeri 2 Kecamatan Sekayu Dalam Mengatasi Konflik Guru}

Dalam menggerakkan atau memotivasi orang lain agar melakukan tindakan- tindakan yang selalu terarah pada pencapaian tujuan organisasi, seorang pemimpin harus memiliki pengetahuan atau kecakapan dan keterampilan yang di perlukan dalam melaksanakan kepemimpinannya. Pengetahuan dan keterampilan tersebut diperoleh dari pengalaman kerja secara teori maupun dari pengalamannya dalam praktek selama menjadi pemimpin.

Dalam melaksanakan kepemimpinannya, berbagai cara di tempuh oleh seorang pemimpin, cara-cara yang di gunakan merupakan pencerminan sikap dan pandangan pemimpin terhadap orang yang di pimpinnya, yang memberikan gambaran pula tentang bentuk atau tipe kepemimpinan yang dijalankan. Tipe kepemimpinan itu diantaranya yaitu: 1) kepemimpinan otokratis; 2) kepemimpinan Laizes Faire; 3) kepemimpinan demokratis.

Berdasarkan hasil wawancara yang peneliti lakukan dengan kepala SD Negeri 2 Kecamatan Sekayu, bendahara sekolah, guru 1, 2, 3, 4 dan guru 5 bahwa kepala sekolah dalam pemimpin yaitu menggunakan tipe kepemimpinan demokratis, karena kepala sekolah selalu melibatkan guru-guru dan staf yang lain dalam penanggulangan konflik antar guru yang mana bertujuan untuk menjaga silaturrahmi antar guru satu dan yang lain, dan kepala sekolah juga memberikan kebebasan kepada guru dan semua staf untuk memberikan ide atau solusi untuk meningkatkan mutu sekolah.

\section{Fungsi Kepala Kepala SD Negeri 2 Kecamatan Sekayu Dalam Mengatasi Konflik Guru}

Fungsi kepala SD Negeri 2 kecamatan Sekayu sangatlah penting untuk dilaksanakan terutama untuk dalam penanggulangan konflik antar guru. Kepala sekolah dan tanggung jawabnya menurut Mulyasa (2013) mempunyai 7 fungsi utama diantaranya, kepala sekolah sebagai educator, kepala sekolah sebagai manajer, kepala sekolah sebagai administrator, kepala sekolah sebagai supervisor, kepala sekolah sebagai leader, kepala sekolah sebagai inovator dan kepala sekolah sebagai motivator. Adapun kepala sekolah sudah menjalankan semua fungsi- fungsinya untuk menanggulangi konflik antar guru di SD Negeri 2 kecamatan Sekayu.

Kepala sekolah sebagai educator. Kepala sekolah sebagai educator dimana kepala sekolah memilki fokus tinggi terhadap perkembangan kurikulum dan kegiatan belajar mengajar tertentu dan akan memperhatikan tingkat belajar memperhatikan tingkat kompetensi yang dimilki guru sekaligus juga akan senantiasa berusaha memfasilitasi dan mendorong agar para guru dapat secara terus menerus meningkatkan kompetensinya. Berdasarkan hasil wawancara yang peneliti lakukan dengan kepala sekolah, bendahara sekolah, guru 1, 2, 3, 4 dan guru 5 bahwa kepala sekolah sudah menjalankan fungsinya sebagai edukator, dimana kepala sekolah selalu mengecek RPP guru-guru serta mengevaluasi kinerja guru.

Kepala sekolah sebagai manajer. Menurut Mulyasa (2013) kepala sekolah sebagai manajer mempunyai peran yang mentukan dalam pengelolaan manajeman sekolah, berhasil tidaknya tujuan sekolah dapat dipengaruhi bagaimana kepala sekolah menjalankan fungsi-fungsi manajeman. Fungsi-fungsi manajeman tersebut adalah planning, organizing, actuating, dan controlling. Berdasarkan hasil wawancara yang peneliti lakukan dengan kepala sekolah, bendahara sekolah, guru 1, 2, 3, 4 dan guru 5 bahwa kepala sekolah sudah menjalankan fungsinya sebagai Manajer, dimana dapat kita lihat beliau sudah melakukan 
pengembangan dan meningkatkan potensi atau kinerja guru, yaitu dengan cara pengirim guru untuk melakukan pelatihan di luar sekolah.

Kepala sekolah sebagai administrator. Menurut Mulyasa (2013) Peranan kepala sekolah sebagai administrator pendidikan berangkat dari hakikat administrasi pendidikan sebagai perndayagunaan berbagai sumber seperti: manusia, sarana dan prasarana serta berbagai media pendidikan lainnya secara optimal, relevan, efektif, dan efisien guna menunjang pencapaian tujuan pendidikan. Berdasarkan hasil wawancara yang peneliti lakukan kepala sekolah, bendahara sekolah, guru 1, 2, 3, 4 dan guru 5 bahwa kepala sekolah sudah menjalankan fungsinya sebagai administrator, dimana beliau menjalankan fungsinya sebagai administrator dengan cara selalu terlibat dalam penyusunan RAPBS, Kepala sekolah juga mengecek sarana dan prasarana yang sudah diinventarisasikan.

Kepala sekolah sebagai supervisor. Menurut Mulyasa (2013) bahwa supervisi merupakan suatu proses yang dirancang secara khusus untuk membantu para guru dan supervisor dalam mempelajari tugas sehari-hari di sekolah, agar dapat menggunakan pengetahuan dan kemampuannya untuk memberikan layanan yang baik pada orang tua peserta didik dan sekolah, serta berupaya menjadikan sekolah sebagai masyarakat belajar yang lebih efektif. Berdasarkan hasil wawancara yang peneliti lakukan dengan kepala sekolah, bendahara sekolah, guru 1, 2, 3, 4 dan guru 5 bahwa kepala sekolah sudah menjalankan fungsinya sebagai supervisor, dimana kepala sekolah telah melakukan supervisi lansung ke kelas kita guru mengajar, Kepala sekolah juga mengamati secara lansung media belajar yang digunakan pada saat proses belajar mengajar berlansung.

Kepala sekolah sebagai leader. Kepala sekolah sebagai leader merupakan salah satu kunci keberhasilannya dalam meningkatkan mutu sekolah yang harus memiliki sifat jujur, percaya diri tanggung jawab dan berani mengabil resiko, kepala sekolah berperan sebagai kekuatan sentral yang menjadi penggerak dalam kehidupan sekolah. Hal lain yang harus dilakukan oleh kepala sekolah sebagai pemimpin kepala sekolah harus mampu mempengaruhi serta memberikan sugesti kepada para guru dalam hal meningkat kan kinerja guru dan kepala sekolah juga mampu mengayomi seluruh masyarkat sekolah. Berdasarkan hasil wawancara yang peneliti lakukan dengan kepala sekolah, bendahara sekolah, guru 1, 2, 3, 4 dan guru 5 bahwa kepala sekolah sudah menjalankan fungsinya sebagai leader, dimana kepala sekolah selalu bertanggung jawab atas kegiatan-kegiatan yang diadakan di sekolah.

Kepala Sekolah Sebagai Inovator. Kepala sekolah harus memiliki strategi yang tepat untuk menjalin hubungan yang harmonis dengan lingkungan, mencari gagasan baru, mengintegrasikan setiap kegiatan, memberikan teladan kepada seluruh tenaga kependidikan sekolah, dan mengembangkan model model pembelajaran yang inofatif. Kepala sekolah sebagai inovator akan tercermin dari cara cara ia melakukan pekerjaannya secara konstruktif, kreatif, delegatif, integratif, rasional, objektif, pragmatis, keteladanan. Berdasarkan hasil wawancara yang peneliti lakukan dengan kepala sekolah, bendahara sekolah, guru 1, 2, 3, 4 dan guru 5 bahwa kepala sekolah sudah menjalankan fungsinya sebagai inovator walaupun belum dapat dikatakan efektif dan efisien sebagai inovator karena kepala sekolah hanya memberikan inovasi pada pembaharuan dalam bidang sapras dan prasarana sekolah.

Kepala Sekolah Sebagai Motivator. Kepala sekolah harus memiliki strategi yang tepat untuk memberikan motivasi kepada pendidik dan tenaga kependidikan dalam melaksanakan tugas dan fungsinya. Motivasi ini dapat ditumbuhkan melalui pengaturan lingkungan fisik, pengaturan suasana kerja, disiplin, dorongan, penghargaan secara efektif, dan penyediaan berbagai sumber belajar melalui pengembangan Pusat Sumber Belajar. Berdasarkan hasil wawancara yang peneliti lakukan dengan kepala sekolah, bendahara sekolah, guru 1, 2, 3, 4 dan guru 5 bahwa kepala sekolah sudah menjalankan fungsinya sebagai motivator, dimana kepala sekolah sudah melakukan beberapa hal sebagai bukti kepala sekolah telah memberikan motivasi kepada seluruh guru dan staf dengan cara memberikan penghargaan kepada guru yang memiliki potensi dan prestasi.

\section{Hambatan Kepala Kepala SD Negeri 2 Kecamatan Sekayu Dalam Mengatasi Konflik Guru}

Pemicu utama konflik ialah perbedaan, dari perbedaan tersebut kemudian berlanjut menjadi pertengkaran atau perselisihan. Sekecil apa pun konflik itu tidak bisa dianggap sepele juga tidak harus disikapi secara berlebihan. Kita bisa mengelola sikap kita dalam menghadapi konflik dengan mengetahui dan memahami akar permasalahannya. Karena kalau konflik di biarkan, maka akan menimbulkan perselisihan yang akan berdampak terhadap perkembangan organisasi, bahkan pihak yang terlibat akan menjadi terancam. Apapun kendala atau hambatan yang terjadi pastinya ada jalan keluar untuk menyelesaikannya, begitu juga halnya dalam menanggulangi konflik antar guru. Berdasarkan hasil wawancara dengan kepala sekolah, bendahara sekolah, guru 1, 2, 3, 4 dan 5, bahwa hanya sedikit hambatan yang dihadapi. Hambatan yang dialami oleh kepala sekolah adalah membutuhkan waktu dan sumber yang jelas untuk mengetahui penyebab dari konflik yang terjadi. Kepala sekolah juga sudah memiliki beberapa cara untuk menyelesaikan masalah yang terjadi antar guru tersebut diantaranya selalu memberi masukan dan arahan serta solusi yang baik untuk semua guru, sehinnga konflik tersebut tidak terulang kembali. 


\section{SIMPULAN}

Hasil penelitian dapat disimpulkan bahwa: 1) konflik yang terjadi pada SD Negeri 2 kecamatan Sekayu ialah terjadinya kecemburuan sosial akibat kesenjangan antara guru aparatur sipil negara dengan guru honorer, adanya grup antar satu guru dengan guru lainnya, adanya ketidaksukaan dari beberapa guru apabila ada guru yang mendapat penghargaan atas keberhasilan yang dia peroleh dari kepala sekolah maupun dari dinas Dikbud; dan 2) peranan manajerial kepala sekolah dalam mengatasi konflik guru di SD Negeri 2 kecamatan Sekayu adalah dengan melakukan beberapa tindakan seperti: (a) berusaha netral dan objektif agar tidak terkesan memihak bila terjadi konflik antar guru; (b) selalu memberikan kesempatan berbicara dan berpendapat kepada semua guru; dan (c) selalu memotivasi guru agar fokus pada peningkatan kompetensinya dan pada tugas serta tanggung jawabnya di sekolah.

\section{UCAPAN TERIMA KASIH}

Terima kasih yang sebesar-besarnya kami ucapkan kepada Kepala Sekolah SD Negeri 2 kecamatan Sekayu, Rektor Universitas PGRI Palembang, Direktur Program Pascasarjana Universitas PGRI Palembang dan Program Studi Manajemen Pendidikan Universitas PGRI Palembang yang telah memberikan dukungan kepada kami untuk melakukan hal yang luar biasa ini. Proyek ini didanai secara independen. Kami juga ingin berterima kasih kepada teman-teman kami di Manajemen Pendidikan yang banyak membantu kami dalam menyelesaikan proyek ini dalam jangka waktu yang terbatas

\section{DAFTAR PUSTAKA}

Anwar, K. (2018). Urgensi Penerapan Manajemen Konflik dalam Organisasi Pendidikan. Alfikri: Jurnal Studi dan Penelitian Pendidikan Islam, 1 (2), 2018.

Arisandi, I., Sitanggang, N., \& Matondang, Z. (2017). Pengaruh Kepemimpinan Kepala Sekolah dalam Manajemen Konflik Berbasis Sekolah dan Motivasi Kerja terhadap Kinerja Guru di SMA Negeri Aceh Tamiang. Jurnal Manajemen Pendidikan 9 (2), Nopember 2017.

Fathoni, A. (2013). Metodologi Penelitian Dan Teknik Penyusunan Skripsi. Jakarta: PT. Rineka Cipta.

Iskandar, A. (2012). Panduan Penelitian Tindakan Kelas Bagi Guru. Jakarta: Gaung Persada.

Isrofi, M. (2017). Peran Manajerial Kepala Sekolah, Lingkungan, Motivasi Guru, terhadap Kinerja Guru Kota Yogyakarta. Jurnal Akuntabilitas Manajemen Pendidikan, 18 (21).

Kristiawan, M., \& Asvio, N. (2018). Pengelolaan Administrasi Madrasah Tsanawiyah Negeri Dalam Meningkatkan Kualitas Pendidikan Madrasah. Kelola: Jurnal Manajemen Pendidikan, 5(1), 86-95.

Liu, M. (2010). Motivating Students Trough Problem-Based Learning. University Of Texas: Austin.

Miles, M. B., \& Huberman, A. M. (2013). Analisa Data Kualitatif. Jakarta: Universitas Indonesia Press.

Moleong, L. J. (2013). Metodologi Penelitian Kualitatif. Bandung: PT Remaja Rosda karya.

Mulyasa, E. (2013). Manajemen Berbasis Sekolah, Konsep, Strategi dan Implementasi. Bandung: PT Remaja Rosdakarya.

Rahmadoni, J. (2018). Global Issues of Education Financing Management in SD Indonesian Creative School Pekanbaru. Jurnal Manajemen, Kepemimpinan, dan Supervisi Pendidikan 3(2), Juli-Desember 2018.

Ruliatawati., Ritonga, A. H., \& Hasibuan, L. (2020). Management Performance Model of Senior High School Teachers of Muhammadiyah in South Sumatera. International Journal of Educational Review, 2 (1).

Suratman, S., Arafat, Y., \& Eddy, S. (2020). The Influence of Principal's Leadership and Teacher's Competence toward Teacher's Performance in Indonesia. Journal of Social Work and Science Education, 1(2), 96104. Retrieved from https://ejournal.karinosseff.org/index.php/jswse/article/view/32

Tampubolon, M. S. (2014). Penelitian Tindakan Kelas sebagai Pengembangan Profesi Pendidikan dan Keilmuan. Jakarta: Erlangga.

Tobari., Kristiawan, M., \& Asvio, N. (2018). The Strategy of Headmaster on Upgrading Educational Quality In Asean Economic Community (AEC) Era. International Journal of Scientific \& Technology Research, 7(4).

Wartini, S. (2015). Instrumen Hukum Pencegahan Pembajakan Hayati (Biopiracy). Jakarta: Lintera.

Zulkarnain, W. (2010). Dasar-Dasar Manajemen dalam Teknologi Informasi. Jakarta: Salemba Empat 